\title{
Effect of phosphorus and sulphur level on growth, yield and oil content of mustard (Brassica juncea L.)
}

\author{
D.P. Singh*, P.K. Upadhyay ${ }^{1}$, M.P. Singh ${ }^{2}$ and Ashutosh Srivastava ${ }^{3}$ \\ C.D.I.C., Lakhpera Kota, B. Ganj, Pratapgarh (U.P.) India
}

\begin{abstract}
A field experiment entitled "Effect of phosphorus and sulphur level on growth and yield of Mustard (Brassica juncea coss.)" variety Varuna, was conducted at the research plot of Kulbhaskar Ashram Post graduate farm Allahabad (U.P.)during the Rabi Season 2008-09 and 2009 - 10 India . The experiment was laid out in a Factorial Randomized Block Design having four levels of phosphorus $\left(0,25,50\right.$ and $\left.75 \mathrm{~kg} \mathrm{ha}^{-1}\right)$ and sulphur $\left(0,20,40\right.$ and $\left.60 \mathrm{~kg} \mathrm{ha}^{-1}\right)$ each with three replications. The phosphorus and sulphur were applied through DAP and gypsum, respectively. Indian mustard variety Varuna was sown on $11^{\text {th }}$ October, 2008 with the seed rate of $5.0 \mathrm{~kg} \mathrm{ha}^{-1}$. The plant height, dry weight per plant, number of siliqua plant ${ }^{-1}$, seed yield and stover yield increased significantly at $50 \mathrm{~kg}$ phosphorus and $40 \mathrm{~kg}$ sulphur ha ${ }^{-1}$. Over without $\mathrm{P}$ and with 25 and $75 \mathrm{~kg} \mathrm{ha}^{-1 .} \mathrm{P}$. and without $\mathrm{S}$ with $20 \mathrm{~kg}$ and $60 \mathrm{~kg} \mathrm{~S}^{-1}$, respectively.
\end{abstract}

Key Words : Phasphorus, Sulphur, Stover

View Point Article : Singh, D.P., Upadhyay, P.K., Singh, M.P. and Srivastava, Ashutosh (2018). Effect of phosphorus and sulphur level on growth, yield and oil content of mustard (Brassica juncea L.). Internat. J. agric. Sci., 14 (2) : 376-380, DOI:10.15740/HAS/IJAS/14.2/376380. Copyright@2018: Hind Agri-Horticultural Society.

Article History : Received : 09.04.2018; Revised : 03.05.2018; Accepted : 18.05.2018

\footnotetext{
* Author for correspondence:

${ }^{1}$ Department of Soil Science, Mahatma Gandhi Chitrakoot Gramodaya Vishwvidyalya, Chitrakoot (U.P.) India

${ }^{2}$ Krishi Vigyan Kendra, Pratapgarh (U.P.) India

${ }^{3}$ Dr. R.M.L. Avadh University, Faizabad (U.P.) India
} 